\title{
Collection of semen in a dog with partial penectomy followed by successful artificial insemination: case report
}

[Coleta de sêmen em um cão parcialmente penectomizado seguida de inseminação artificial bem sucedida: relato de caso]

\author{
S.B. Oliveira ${ }^{1}$, L.F.L. Ferreira ${ }^{1}$, T.F. Carvalho ${ }^{2}$, R.L. Santos $^{2}$, G.R. Valle ${ }^{1 *}$ \\ ${ }^{1}$ Pontifícia Universidade Católica de Minas Gerais - Belo Horizonte, MG \\ ${ }^{2}$ Escola de Veterinária - Universidade Federal de Minas Gerais - Belo Horizonte, MG
}

\begin{abstract}
This study describes a case of a dog with a lacerated penile tear treated with partial penectomy followed by successful semen collections for artificial insemination. A 1.5-year-old Jack Russel Terrier with normal libido, genital organs and semen, had a penile laceration after copulation. The dog underwent a partial penectomy without orchiectomy, thus preserving the possibility of semen collection. Semen was successfully collected at 45 and 53 days after surgery, and it was used for artificial insemination of two bitches, one of which became pregnant. Therefore, this report demonstrated that semen may be collected from dogs with partial penectomy for artificial insemination, this technique has the potential to preserve fertility of dogs with penile lesions that require penectomy.
\end{abstract}

Keywords: dog, partial penectomy, semen collection, fertility

\section{RESUMO}

Este estudo descreve o caso de um cão que teve laceração peniana tratada por penectomia parcial seguida de coleta de sêmen para inseminação artificial bem sucedida. Um cão Jack Russel Terrier de 1,5 anos, com libido, órgãos genitais e sêmen normais, teve laceração peniana após cópula. O cão foi parcialmente penectomizado sem orquiectomia, preservando a possibilidade de coleta de sêmen. A coleta de sêmen foi bem sucedida 45 e 53 dias após a cirurgia, sendo utilizado para inseminação artificial de duas cadelas, uma delas se tornando gestante. Portanto, sêmen para inseminação artificial pode ser coletado em cães parcialmente penectomizados, esta técnica revelando ser uma potencial forma de preservação da fertilidade de cães com lesões penianas que necessitem penectomia.

Palavras-chave: cão, penectomia parcial, coleta de sêmen, fertilidade

\section{INTRODUCTION}

Penile traumatic injuries in dogs often require penectomy, which is usually associated with orchiepididymectomy and perianal urethrostomy (Burrow et al., 2011) resulting in infertility, an important sequel after a penile trauma. Cryopreservation of epididymal spermatozoa immediately after orchiepididymectomy may be an alternative for reproduction under these conditions (Luvoni and Morselli, 2007), but this procedure is limited to the number of live spermatozoa obtained after a single cryopreservation procedure.

Although not conventional, partial penectomy has been described to treat penile injuries in dogs (Pavletic and O'Bell, 2007). However, to the best of our knowledge, the use of partial penectomy without orchiepididymectomy and perianal urethrostomy in penile injured dogs, maintaining fertility by semen collection and artificial insemination (AI), has not been previously reported.

Recebido em 29 de fevereiro de 2020

Aceito em 4 de junho de 2020

*Autor para correspondência (corresponding author)

E-mail: guilhermerv@pucminas.br 


\section{Oliveira et al.}

\section{CASUISTRY}

A 1.5-year-old Jack Russel Terrier with normal libido, testicles measuring $15 \times 28 \mathrm{~mm}$ and normal consistency, and prominent cauda of the epididymis was examined for reproductive purposes. Semen was collected by masturbation near a bitch in heat, using a conventional method
(Kutzler, 2005) adapted by Valle et al. (2012), producing $3.4 \mathrm{~mL}$ of semen with 576 million spermatozoa per ejaculate; $80 \%$ progressive motility (PM); fast speed (S); and 76\% morphologically normal spermatozoa (Table 1). On the same day, after copulating a bitch, the dog had a penis laceration on the pars longa (Figure 1). The copulation resulted in pregnancy.

Table 1 . Semen characteristics of the dog before and after surgery

\begin{tabular}{lcclcl}
\hline Ejaculate & $\begin{array}{l}\text { Volume } \\
(\mathrm{mL})\end{array}$ & $\begin{array}{l}\text { Progressive } \\
\text { Motility }(\%)\end{array}$ & Speed * & $\begin{array}{l}\text { Spermatozoa } \\
\text { lejaculate }\left(10^{6}\right)\end{array}$ & $\begin{array}{l}\text { Normal } \\
\text { spermatozoa }(\%)\end{array}$ \\
\hline 2 d before surgery & 3.4 & 80 & fast & 576 & 76 \\
45 d after surgery & 2.5 & 40 & slow & 98 & not evaluated \\
53 d after surgery & 4.0 & 60 & moderate & 411 & not evaluated \\
\hline
\end{tabular}

* Speed estimated as fast, moderate and slow.

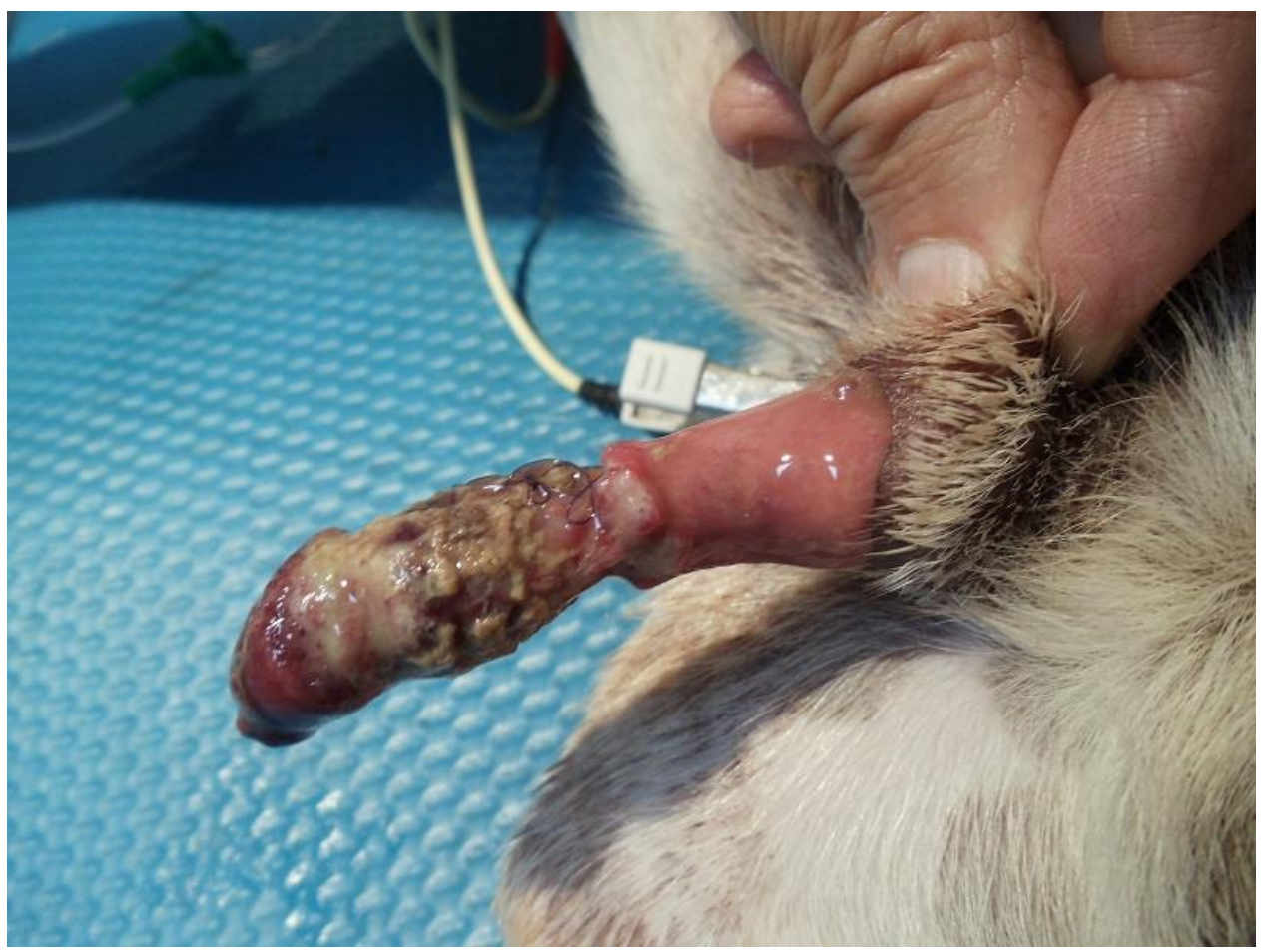

Figure 1. Pars longa of the penis lacerated and with tissue necrosis.

Conservative treatment of the wound was tried. The wound was cleaned with saline three times a day, cefalexin $30 \mathrm{mg} / \mathrm{kg}$ per os $12 / 12 \mathrm{~h}$ was administered and the dog was kept with Elizabethan collar for two days, when necrosis was observed. Partial ablation of the penis was performed after failure of the conservative treatment, using an adapted technique from those previously described (Pavletic and O'Bell, 2007; Burrow et al., 2011), which preserved the testicles without urethrostomy. The dog underwent general anesthesia. A tourniquet was positioned caudally to the injury, and a urethral catheter was placed. After a transverse incision cranial to the tourniquet the penile bone was sectioned with the aid of a gum plier.

After a transversal incision of the urethra, total ablation of the lacerated pars longa was performed. Dorsal penile blood vessels were ligated, and the urethra was sutured to the tunica albuginea using nylon thread number 4-0 in a 
single simple pattern. The prepuce remained intact. The urethral catheter was maintained for 2 days. Analgesic (tramadol $4.0 \mathrm{mg} / \mathrm{kg}$ per os $12 / 12 \mathrm{~h}$ ), anti-inflammatory (meloxican $0.1 \mathrm{mg} / \mathrm{kg}$ per os 24/24h), and antibiotic (cefalexin $30 \mathrm{mg} / \mathrm{kg}$ per os $12 / 12 \mathrm{~h}$ ) treatments were administered for 5 days. Stitches were removed 15 days after surgery. The option to avoid preputial urethrostomy was to keep the possibility of future semen collection.

Semen was successfully collected at 45 and 53 days after surgery using the same technique employed before surgery (Valle et al., 2012). On the first day, the dog initially refused penile manipulation, but finally erection and ejaculation were obtained with the remaining penis inside the prepuce $(2.5 \mathrm{~mL} ; 98$ million spermatozoa per ejaculate; $40 \%$ PM; slow S). On the second day, the dog presented normal libido and erection and ejaculation was easily achieved with exposure of the bulbus glandis (Figure 2), producing $4.0 \mathrm{~mL}$ of semen with 411 million spermatozoa per ejaculate; 60\% PM and moderate S. Each ejaculate (Table 1) was used for deep intravaginal AI (Johnston et al., 2001) of two bitches, the first with the first ejaculate (45 days post-surgery), and the second with the second ejaculate (53 days post-surgery). Both bitches were submitted to identification of the fertile days for AI using vaginal cytology and serum progesterone dosage (Johnston et al., 2001). The second bitch became pregnant and delivered three healthy puppies.
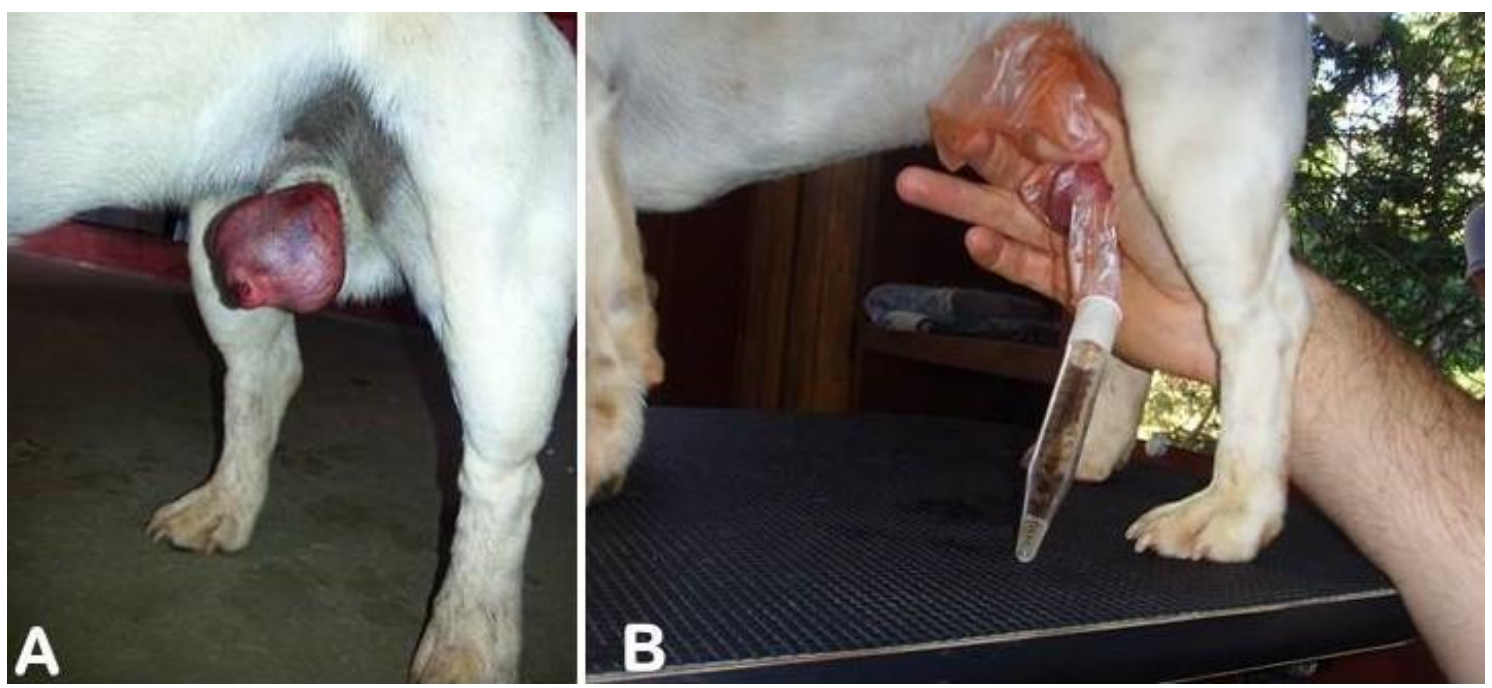

Figure 2. (A) The dog with partially ablated penis and bulbus glandis erection. (B) Collection of semen by masturbation, the hand grasping the erectile bulbus glandis, and semen inside tube.

The owner of the dog signed a Free and Informed Consent Term, and all procedures described in this report strictly followed all applicable legislation and animal welfare guidelines.

\section{DISCUSSION}

There are several reasons for semen collection and its use for AI instead of the natural copula, including the use of cryopreserved or chilled semen, bitches with vulvo-vaginal anomalies, behavioral incompatibilities between dog and bitch, and breed related difficulties to copulate (Johnston et al., 2001; Kutzler, 2005). However, the use of AI for dogs submitted to penectomy after trauma has not been previously reported.
Insufficient sexual stimulation may cause disturbances of ejaculation, such as no ejaculation or incomplete ejaculation, compromising fertility (Root et al., 1994; Kustritz and Hess, 2007; Lopate, 2007). In humans (Nimbi et al., 2020), sex desire is described as a subjective psychological status to initiate sexual behavior, preceding arousal, orgasm and resolution. Its components are drive (biological aspects of neuroendocrine system), motivation (mental, relational and social psychological aspects) and wish (cultural aspect including moral values). These aspects are not well known in the case of animals, but erection and ejaculation can be impaired by fear and pain (Kutzler, 2005), and the 
initial refuse for semen collection by the dog at the first tentative after trauma may have resulted from the psychological influence of the previous traumatic experience and/or pain during genital manipulation.

However, the blockage of motivation in this dog with partial penectomy may be supplanted by the neuroendocrine stimuli due to the presence of a bitch in heat and the genital tactile stimulation during collection procedures, and erection and ejaculation obtained as the dog felt pleasant feelings. The drive is a predisposition to respond to sexual stimuli achieving sexual excitement (Nimbi et al., 2020), and the previous exposure of the dog to the pleasant feelings associated to semen collection may have had a positive influence in this case. Previous good or bad experiences affect the success of semen collection in dogs (Kutzler, 2005).

Genital tactile stimulation is only part of the stimuli (Corona et al., 2012) that triggers neuronal (Traas and Kustritz, 2004) and hormonal (Hess, 2006) pathways for erection and ejaculation. However, although the dog had reduced the area for tactile stimulation after penectomy, libido, erection of the remaining penis, and ejaculation were preserved after surgery, which is similar to previous reported cases of horses with penectomy (Silva et al., 1995; Schumacher and Varner, 2011). The technique for semen collection in dogs includes initial manual stimulation of the penis inside the preputial sheath, at the level of the bulbus glandis, followed by penile exposure and squeezing with fingers behind bulbus glandis (Kutzler, 2005). Therefore, the pars longa is not stimulated during the traditional method of semen collection, and seems to not be required for semen collection, as observed in this case.

\section{CONCLUSION}

In conclusion, partial penectomy without urethrostomy preserved dog fertility by using semen collection and AI in this case and may be recommended for dogs with penile trauma that are desired for reproduction.

\section{ACKNOWLEDGEMENTS}

The authors would like to thank professor Homem Israel Ferreira (in memoriam) for the valorous contribution in the surgical procedures in this case; and the dog's owner, Mrs. Silvia Gerhardt.

\section{REFERENCES}

BURROW, R.D.; GREGORY, S.P.; GIEJDA, A.A. et al. Penile amputation and scrotal urethrostomy in 18 dogs. Vet. Rec., v.169, p.657, 2011.

CORONA, G.; JANNINI, E.A.; VIGNOZZI, L. et al. The hormonal control of ejaculation. Nat. Rev. Urol., v.9, p.508-519, 2012.

HESS, M. Documented and anecdotal effects of certain pharmaceutical agents used to enhance semen quality in the dog. Theriogenology, v.66, p.613-617, 2006.

JOHNSTON, S.D.; KUSTRITZ, M.V.R.; OLSON, P.N.S. Breeding management and artificial insemination of the bitch. In:

Canine and feline theriogenology. Philadelphia: W.B. Saunders Co., 2001. p.41-65.

KUSTRITZ, M.; HESS, M. Effect of administration of prostaglandin F2alpha or presence of an estrous teaser bitch on characteristics of the canine ejaculate. Theriogenology, v.67, p.255-258, 2007.

KUTZLER, M.A. Semen collection in dog. Theriogenology, v.64, p.747-754, 2005.

LOPATE, C. The problem stud dog. Vet. Clin. N. Am. Small. Anim. Pract., v.42, p.469-488, 2007.

LUVONI, G.C.; MORSELLI, M.G. Canine epididymal spermatozoa: a hidden treasure with great potential. Reprod. Domest. Anim., v.52, Suppl.2, p.197-201, 2017.

NIMBI, F.M.; TRIPODI, F.; ROSSI, R. et al. Male sexual desire: an overview of biological, psychological, sexual, relational, and cultural factors influencing desire. Sex. Med. Rev., v.8, p.59-91, 2020.

PAVLETIC, M.M.; O'BELL, S.A. Subtotal penile amputation and preputial urethrostomy in a dog. J. Am. Vet. Med. Assoc., v.230, p.375-377, 2007. 
ROOT, M.V.; JOHNSTON, S.D.; OLSON, P.N. Concurrent retrograde ejaculation and hypothyroidism in a dog. Theriogenology, v.41, p.593-600, 1994.

SCHUMACHER, J.; VARNER, D.D. Surgery of the penis and prepuce. In: MCKINNON, A.O.; SQUIRES, E.L.; VAALA, W.E. et al. (Eds.). Equine reproduction. Ames: Wiley Blackwell, 2011. p.1562-571.

SILVA, L.A.F.; CARNEIRO, M.I.; FIORAVANTI, M.C.S. et al. Técnica de circuncisão com encurtamento do pênis para obtenção de rufiões equinos. Arq. Bras. Med. Vet. Zootec., v.47, p.789-798, 1995.
TRAAS, A.M.; KUSTRITZ, M.V.R. Effect of administrating oxytocin or prostaglandina F2alfa on characteristics of the canine ejaculate. Can. Vet. J., v.45, p.999-1002, 2004.

VALLE, G.R.; ANDRADE, C.R.G.; SILVA, L.C. et al. Utilização de cones de polietileno para coleta de sêmen canino. Rev. Bras. Reprod. Anim., v.36, p.250-255, 2012. 